\title{
Studies on the Immunomodulatory Effects of Lactoferrin in Rats Infected with $E$. coli
}

\author{
Mohamed El-Sayed El-Boshy ${ }^{1,2 *}$, Osama Ali Abdalla ${ }^{3}$, Adal Hassan ${ }^{3}$ \\ ${ }^{1}$ Department of Clinical Pathology, Faculty of Veterinary Medicine, Mansoura University, Mansoura, Egypt \\ ${ }^{2}$ Laboratory Medicine Department, Faculty of Applied Medical Science, \\ Umm Al-Qura University, Makkah, Saudi Arabia \\ ${ }^{3}$ Department of Clinical Pathology, Faculty of Veterinary Medicine, Ismailia, Egypt \\ Email: ${ }^{2}$ ahmedmed32@yahoo.com
}

Received May 17, 2013; revised June 24, 2013; accepted July 10, 2013

Copyright (C) 2013 Mohamed El-Sayed El-Boshy et al. This is an open access article distributed under the Creative Commons Attribution License, which permits unrestricted use, distribution, and reproduction in any medium, provided the original work is properly cited.

\begin{abstract}
Eighty male albino rats of Westar strain $(350 \pm 10 \mathrm{~g}), 10$ to 12 weeks old were divided into four groups. The groups treated are as following. The first control group (Gp. I) was given intraperitoneally in normal saline (1 mL). The second group (Gp. II) was orally infected with $3 \times 10^{12} \mathrm{CFU}$ of $E$. coli $/ \mathrm{Kg}$. BW. The third group (Gp. III) was infected with $E$. coli and treated with $(0.5 \%)$ lactoferrin $(\mathrm{LF}) 72$ hours before $E$. coli infection in filtered tap water for the duration of the experiment (21 days). The fourth group (Gp. IV) was administrated with LF only (0.5\%) in drinking water. Two separate blood samples were collected from heart puncture at the end of $1^{\text {st }}$, and $3^{\text {rd }}$ week post-treatment for immunological studies. The Leukogram in E. coli treated group was insignificant compared with the control group while lymphocytosis was clear compared with the infected group. Total protein, albumin, $\alpha$-globulin and $\beta$-globulin were insignificantly changed in LF \& E. coli treatment group comparing with infected and control groups. TNF- $\alpha$ and $\gamma$-globulin are significantly increased in infected group comparing with other treated groups. In conclusion, lactoferrin has powerful antibacterial activity in a variety of ways as well as a safe immunostimulant protein when it is orally administrated.
\end{abstract}

Keywords: Lactoferrin; Immunomodulatory; E coli; Rats

\section{Introduction}

Escherichia coli is probably the best-known bacterial specie and one of the most frequently isolated organisms from clinical specimens [1].

Lactoferrin is (LF) a very important part of the human body's natural defense system, sequestering free iron result in inhibition, adhesion and growth of (pathogens) like H. pylori and E. coli to the intestinal wall. The cellular structure of pathogens loses its integrity due to the iron deprivation and necrosis [2]. LF and its derivatives have pleiotropic functions including broad-spectrum antimicrobial activity, regulation of cell growth and differentiation, and modulation of inflammatory as well as humoral and cellular immune responses [3].

Escherichia coli is one of the main species of bacteria that normal inhabitants lower intestines of worm blooded animals, including birds and mammals [4].

LF is a natural defense protein belonging to the innate

"Corresponding author. immune system present in several body fluids and secretions, as well as in the secondary granules of polymorphonuclear neutrophils [3]. LF has been thought to protect against gram-negative bacteria in a variety of ways. It sequesters iron that is essential for bacterial growth [5]. It has reported that orally administered bovine lactoferrin (bLF) inhibits the proliferation of endogenous members of the family Enterobacte-riaceae in the guts of mice fed bovine milk [6]. (It was shown also that orally administered bLF into mice inhibits bacterial translocation [7].

Therefore, the goals of this study are safety evaluation of antimicrobial activity of LF in rat experimentally infected with $E$. coli through measuring some selective immunological parameters.

\section{Material \& Methods}

\subsection{Materials}

Experimental Animals (Rats)

Eighty male albino rats of Westar strain $(350 \pm 10 \mathrm{~g})$, 
to 12 weeks old procured from College of Veterinary Medicine Zagazig University, Egypt, were used for the study. Animals were fed with commercially available standard and balanced rat ration and water was provided ad libitum. The rats were housed under controlled conditions of humidity, temperature $\left(25^{\circ} \mathrm{C} \pm 2^{\circ} \mathrm{C}\right)$ and light $(12$ $\mathrm{h}$ light $/ 12 \mathrm{~h}$ dark) and had free access to water and food. All animals were acclimatized for 1 week before experimentation and experiment extended for 21 days.

Bovine lactoferrin (bLF) was purchased from (Symbiotics Co lustrum U.S.A. (lot no. MLF 160996;) was obtained from bovine colostrums. It was a light red pink powder, almost odorless, with a purity of $100 \% \mathrm{bLF}$.

E. coli O78, strain was provided by (Animal Health Research Center, Ismailia, Egypt).

\subsection{Methods}

Rats were randomly divided into four equal groups, each consisting of twenty rats. Each group separated in Plastic cages. The groups treated as following. $1^{\text {st }}$ control group (Gp. I) was given intraperitoneally normal saline $(1 \mathrm{~mL})$. $2^{\text {nd }}$ group $(\mathrm{Gp} . \mathrm{II})$ was orally infected with $3 \times 10^{12} \mathrm{CFU}$ of $E$. coli $/ \mathrm{Kg}$. BW according to Lyn et al. [8]. $3^{\text {rd }}$ group (Gp. III) infected with E. coli and treated with bLF $(0.5 \%)$ in filtered tap water for the duration of the experiment (21 days). $4^{\text {th }}$ group (Gp. IV) administrated lactoferrin only $(0.5 \%)$ in drinking water according to Zimecki et al. [9]. The experiment extends for 21 days post treatment.

\subsubsection{Blood Sampling}

Two separate blood samples were collected from heart puncture at end of $1^{\text {st }}$ and $3^{\text {rd }}$ week post treatment. One sample was taken in epindorf tubes at which mixed with EDTA for total and differential leukocytes counts which were measured according to $[10,11]$ respectively. The second blood samples were taken in test tube without anticoagulant. The samples were centrifuged at $3000 \mathrm{rpm}$ for 10 minutes and the clear serum was separated carefully and determination of some biochemical parameters (total protein and albumin) by using commercial diagnostic kits which were obtained from Human-Germany and Spinreact-Spanish).

Immunoelectrophoresis of serum protein has been done using cellulose acetate gel according to [12].

Tumor necrosis factor - $\alpha$ (TNF) was measured by Enzyme Amplified Sensitivity Immunoassay (EASIA) performed on microplate. The assay used monoclonal antibodies (MAbs) directed against distinct epitopes of TNFaccording to [13].

\subsubsection{Statistical Analysis}

The results were analyzed by analysis of variance (ANOVA) followed by LSD using SPSS.18 for window. Two groups were significantly different if $\mathrm{P}$ was statisti- cally lower than 0.05 .

\section{Results \& Discussion}

Lactoferrin is a protein found in cow milk and human milk. Colostrum, the first milk produced after a baby is born, contains high levels of lactoferrin, which is about seven times the amount found in milk produced later on. Lactoferrin is also found in fluids in the eye, nose, respiratory tract, intestine, and elsewhere [14].

Infected group in the present work showed marked leukocytosis and neutrophilia in agreement with Shin et al. [2] who found that Shiga toxin of E. coli caused marked (seven fold) granulocytosis in the peripheral blood. Tanka et al. [15] demonstrated that I/p injection of E.coli lipopolysaccharid (LPS) stimulates inflammatory response. The response in turn, caused release of chemical mediators such as macrophage colony stimulating factor which in turn activates various cell systems as macrophage and neutrophils.

The current results of our study revealed that the LF and $E$.coli treated group show significant decrease in leuckocytes comparing with infected group and return to normal level during $3^{\text {rd }}$ weeks (Tables 1 \& 2). The antibacterial activity of LF is not only due to its iron binding capacity Visca et al. [16] but also due to neutralizing the endotoxins, binding to the bacterial cell and protective activity against lethal E. coli infection by lactoferrin. This result agreed with Lynn et al. [8] who reported that orally administered LF protected neonatal rats from systemic bacterial infection, illness, and death following massive intestinal infection with E. coli. In the same line, Liliana et al. [17] recorded that the numbers of bacteria in the kidneys and bladder of $E$. coli treated mice were significantly reduced $24 \mathrm{~h}$ later by the LF treatments compared to the findings for the control group. Zagulski et al. [18] reported that LF I/V injected to mice, with dose of $E$. coli, lead to strong clearance of $E$. coli from blood as well as liver, lungs, spleen and kidney.

Current result revealed significant lymphocytosis in LF and E. coli treated group comparing with infected group. Also increased lymphocyte counts in LF group comparing with control one. This could be attributed to LF which activated natural killer cells as well as promoted maturation of $\mathrm{T}$ and $\mathrm{B}$ cells from neonatal mice [9].

Concerning to plasma protein profile of this result, insignificant alteration of total plasma protein, alpha and beta globulins in infected group comparing with control one was shown (Tables $3 \& 4$ ). This may be as a result of increased synthesis of acute phase protein by $E$. coli infection von et al. [19] as well as dehydration. Current result partially in hand with Kinsbergen et al. [20] who reported insignificant change in total plasma protein in calves I/V injected with $E$. coli. 
Table 1. Leukogram (mean $\pm \mathrm{SE}$ ), one week post treatment with lactoferrin in immunosuppressed rats with $E$. coli.

\begin{tabular}{ccccccc}
\hline Groups & TLC $10^{3} / \mu \mathrm{L}$ & Neutrophil $10^{3} / \mu \mathrm{L}$ & Eosinophil $10^{3} / \mu \mathrm{L}$ & Basophil $10^{3} / \mu \mathrm{L}$ & Lymphocyt $10^{3} / \mu \mathrm{L}$ Monocyte $10^{3} / \mu \mathrm{L}$ \\
\hline Control (I) & $7.75^{\mathrm{a}} \pm 0.45$ & $2.74^{\mathrm{a}} \pm 0.25$ & $0.154^{\mathrm{b}} \pm 0.041$ & $0.016^{\mathrm{a}} \pm 0.01$ & $4.39^{\mathrm{a}} \pm 0.31$ & $0.47^{\mathrm{a}} \pm 0.072$ \\
E. coli (II) & $14.27^{\mathrm{c}} \pm 1.24$ & $9.06^{\mathrm{c}} \pm 0.89$ & $0.021^{\mathrm{a}} \pm 0.019$ & 0.00 & $4.65^{\mathrm{a}} \pm 0.41$ & $0.54^{\mathrm{a}} \pm 0.075$ \\
Lactoferrin \& E. coli (III) & $9.51^{\mathrm{b}} \pm 0.41$ & $4.35^{\mathrm{b}} \pm 37$ & $0.125^{\mathrm{b}} \pm 0.035$ & 0.0 & $4.51^{\mathrm{a}} \pm 0.39$ & $0.52^{\mathrm{a}} \pm 0.063$ \\
Lactoferrin (IV) & $8.35^{\mathrm{a}} \pm 0.59$ & $2.52^{\mathrm{a}} \pm 0.29$ & $0.138^{\mathrm{b}} \pm 0.0 .39$ & $0.017^{\mathrm{a}} \pm 0.01$ & $5.09^{\mathrm{a}} \pm 0.36$ & $0.56^{\mathrm{a}} \pm 0.071$ \\
\hline
\end{tabular}

Means in the same column not followed by the same letter differ significantly $(P<0.05)$.

Table 2. Leukogram (mean $\pm \mathrm{SE}$ ), one week post treatment with lactoferrin in immunosuppressed rats with $E$. coli.

\begin{tabular}{ccccccc}
\hline Groups & TLC $10^{3} / \mu \mathrm{L}$ & Neutrophil $10^{3} / \mu \mathrm{L}$ & Eosinophil $10^{3} / \mu \mathrm{L}$ & Basophil $10^{3} / \mu \mathrm{L}$ & Lymphocyt $10^{3} / \mu \mathrm{L}$ Monocyte $10^{3} / \mu \mathrm{L}$ \\
\hline Control (I) & $8.35^{\mathrm{a}} \pm 0.51$ & $2.53^{\mathrm{a}} \pm 0.28$ & $0.165^{\mathrm{b}} \pm 0.044$ & $0.016^{\mathrm{a}} \pm 0.016$ & $5.18^{\mathrm{b}} \pm 0.36$ & $0.46^{\mathrm{a}} \pm 0.051$ \\
E. coli (II) & $8.30^{\mathrm{a}} \pm 0.48$ & $3.46^{\mathrm{a}} \pm 0.35$ & $0.034^{\mathrm{a}} \pm 0.016$ & 0.00 & $4.02^{\mathrm{a}} \pm 0.34$ & $0.78^{\mathrm{b}} \pm 0.055$ \\
Lactoferrin \& E. coli (III) & $8.68^{\mathrm{a}} \pm 0.42$ & $2.89^{\mathrm{a}} \pm 0.29$ & $0.174^{\mathrm{b}} \pm 0.030$ & 0.00 & $4.91^{\mathrm{a}} \pm 0.31$ & $0.71^{\mathrm{b}} \pm 0.048$ \\
Lactoferrin (IV) & $8.91^{\mathrm{a}} \pm 0.57$ & $2.98^{\mathrm{a}} \pm 0.31$ & $0.178^{\mathrm{b}} \pm 0.034$ & $0.089^{\mathrm{a}} \pm 0.09$ & $5.29^{\mathrm{b}} \pm 0.34$ & $0.37^{\mathrm{a}} \pm 0.065$ \\
\hline
\end{tabular}

Means in the same column not followed by the same letter differ significantly $(P<0.05)$.

Table 3. Some selective immunological parameters one week post treatment with lactoferrin mean \pm SE) in immunosuppressed rats with $E$. coli.

\begin{tabular}{ccccccc}
\hline Groups & T. Protein gm/dl & Albumin gm/dl & $\boldsymbol{\alpha}$-globulin gm/dl & $\boldsymbol{\beta}$-globulin gm/dl & $\boldsymbol{\gamma}$-globulin gm/dl & TNF-P g/ml \\
\hline Control (I) & $7.45^{\mathrm{a}} \pm 0.41$ & $3.40^{\mathrm{a}} \pm 0.25$ & $1.41^{\mathrm{a}} \pm 0.18$ & $1.35^{\mathrm{a}} \pm 0.17$ & $1.29^{\mathrm{b}} \pm 012$ & $21.2^{\mathrm{a}} \pm 2.45$ \\
E. coli (II) & $7.67^{\mathrm{a}} \pm 0.54$ & $3.21^{\mathrm{ab}} \pm 0.34$ & $1.74^{\mathrm{a}} \pm 0.12$ & $1.81^{\mathrm{b}} \pm 0.14$ & $0.91^{\mathrm{a}} \pm 0.08$ & $54.6^{\mathrm{b}} \pm 6.25$ \\
Lactoferrin \& E. coli (III) & $7.64^{\mathrm{a}} \pm 0.61$ & $3.25^{\mathrm{ab}} \pm 0.31$ & $1.69^{\mathrm{a}} \pm 0.11$ & $1.72^{\mathrm{b}} \pm 0.10$ & $0.98^{\mathrm{a}} \pm 0.06$ & $44.6^{\mathrm{b}} \pm 5.41$ \\
Lactoferrin (IV) & $7.52^{\mathrm{a}} \pm 0.62$ & $3.38^{\mathrm{a}} \pm 0.46$ & $1.46^{\mathrm{a}} \pm 0.19$ & $1.32^{\mathrm{a}} \pm 0.16$ & $1.36^{\mathrm{b}} \pm 0.13$ & $20.4^{\mathrm{a}} \pm 2.01$ \\
\hline
\end{tabular}

Means in the same column not followed by the same letter differ significantly $(P<0.05)$.

Table 4. Some selective immunological parameters three week post treatment with lactoferrin (mean \pm SE) in immunosuppressed rats with $E$. coli.

\begin{tabular}{ccccccc}
\hline Groups & T. Protein gm/dl & Albumin gm/dl & $\boldsymbol{\alpha}$-globulin gm/dl & $\boldsymbol{\beta}$-globulin gm/dl & $\boldsymbol{\gamma}$-globulin gm/dl & TNF-Pg/ml \\
\hline Control (I) & $7.48^{\mathrm{a}} \pm 0.48$ & $3.46^{\mathrm{a}} \pm 0.23$ & $1.39^{\mathrm{a}} \pm 0.16$ & $1.31^{\mathrm{a}} \pm 0.17$ & $1.32^{\mathrm{b}} \pm 014$ & $18.9^{\mathrm{a}} \pm 2.08$ \\
E. coli (II) & $6.39^{\mathrm{a}} \pm 0.42$ & $2.86^{\mathrm{a}} \pm 0.21$ & $1.35^{\mathrm{a}} \pm 0.13$ & $1.25^{\mathrm{a}} \pm 0.14$ & $0.94^{\mathrm{a}} \pm 0.08$ & $46.1^{\mathrm{b}} \pm 5.15$ \\
Lactoferrin \& E. coli (III) & $7.21^{\mathrm{a}} \pm 0.56$ & $3.26^{\mathrm{ab}} \pm 0.20$ & $1.34^{\mathrm{a}} \pm 0.14$ & $1.35^{\mathrm{a}} \pm 0.13$ & $1.28^{\mathrm{b}} \pm 0.10$ & $23.7^{\mathrm{a}} \pm 2.82$ \\
Lactoferrin (IV) & $7.52^{\mathrm{a}} \pm 0.49$ & $3.38^{\mathrm{a}} \pm 0.32$ & $1.33^{\mathrm{a}} \pm 0.16$ & $1.32^{\mathrm{a}} \pm 0.18$ & $1.48^{\mathrm{b}} \pm 0.15$ & $19.4^{\mathrm{a}} \pm 1.95$ \\
\hline
\end{tabular}

The present result showed hyoalbuminemia in the $3^{\text {rd }}$ week in E. coli infected group comparing with control one. E. coli infection caused hypoalbuminemia in rats due to fall in the levels of albumin mRNA in response to infection parallel to a decrease in intrahepatic albumin synthesis. Also, infection can lead to increased catabolic rate and/or redistribution of albumin from plasma to interstitial compartment. Also, infection could be attributed to malabsorption as a result of the diseases affecting the GIT especially the intestine. Total plasma protein and albumin were insignificantly different in E. coli and LF in comparison with the control one. In addition, Andréa and Loreny [21] recorded that LF inhibit the adhesion of enteropathogenic $E$. coli to the intestinal epithelial cells. $\gamma$ globulin in the present work was decreased in E. coli infected group comparing with the control one. This could be due to the immunosuppression of E. coli. Immunosuppression of E. coli, has been reported with different authors; [22-24] in rats, calve and healthy volunteers respectively.

Regarding to $\gamma$-globulins in LF and E. coli, treated group showed significant increase of $\gamma$-globulins comparing with infected group and returned to normal at $3^{\text {rd }}$ week. LF and its derivatives have pleiotropic functions regulation of cell growth and differentiation, and modulation of inflammatory as well as humoral and cellular immune responses [3]. LF could induce cytokine production in stromal cells, who are able to support differentia- 
tion of $\mathrm{T}$ and $\mathrm{B}$ cells [25]. LF exerts a beneficial action on the immune response, inducing lymphocyte proliferation and good inducer of IL-6 [26]. $\gamma$-globulins in LF group showed insignificant differences comparing with control group. This result was the same with Jaya and Shaoo [27] who reported that oral feeding of LF potentially stimulate non-specific immune response while specific immunity was not influenced by LF feeding.

Tumor necrosis factor $\alpha$ is the principal cytokines produced by activated $\mathrm{T}$ cells, mononuclear phagocytes and NK cells to induce cell mediated immune responses to foreign agents [28]. TNF- $\alpha$ was significantly increased in $E$. coli infected group comparing with the control one. This result goes with Theodore [29] who recorded the most marked acute phase reactions in responses to $E$. coli are the greatest TNF- $\alpha$ responses in blood plasma. This result also agreed with Zimecki et al. [30] who reported that I.V. administration of lethal dose of $E$. coli leading to an increase of TNF- $\alpha$ level. In the presented study, TNF- $\alpha$ was significantly decreased in E. coli and LF treated group comparing with infected one at $2^{\text {nd }}$ week and return to the normal at $3^{\text {rd }}$ week. In the same line, the Zimecki et al., [30] concluded the protective action of LF in $E$. coli induced bacteremia by revealing the phenomenon of accelerated neutrophil recruitment and down regulation of E. coli-induced TNF alpha serum level. Also, Adamik \& Wlaszczyk [31] contribute the protection action of LF against pathogens and their metabolites to enhance phagocytosis, cell adherence and controlling release of proinflammatory cytokines such as TNF-alpha. Spagnuolo et al. [32] reported that short-term dietary LF decreased TNF alpha expression in intestinal lymphocyte in healthy mice. Crouch et al. [33] concluded that LF may modulate immune responses by inhibiting cytokine activity (TNF- $\alpha$ ). This result is in contradiction with Teraguchi, et al. [34] who observed increase cytokine (IFN- $\gamma$, TNF- $\alpha$, IL-12, and IL-18) production in response to LF administration in several animal models.

During the experiment period, there are none significant changes in the LF treated group comparing with control group in all investigated items which indicate high safety profile of LF. This result agreed with Yamauchi et al. [35], who reported no significant toxilogical results in male and female rats treatment with 2000 $\mathrm{mg} / \mathrm{kg}$. BW/of LF is once daily for 13 weeks.

In conclusion, LF has been thought to be powerful antibacterial agent in a variety of ways as well as is a safe immunostimulant protein when orally administrated, for a long time without any observed adverse effect.

\section{REFERENCES}

[1] D. Mark, C. Annette and B. Jean, "Estimated Annual Costs Due to Selected Food-Borne Pathogens," Data from the Centers for Disease Control and Prevention, Food-
Related Illness and Death in the United States Economic Research Service, US Department of Agriculture, 2001.

[2] K. Shin, K. Yamauchi, S. Teraguchi, H. Hayasawa, M. Tomita, Y. Otsuka and S. Yamazaki, "Antibacterial Activity of Bovine Lactoferrin and Its Peptides against Enterohaemorrhagic Escherichia coli O157:H7," Letters in Applied Microbiology, Vol. 26, 1998, pp. 407-411. http://dx.doi.org/10.1046/j.1472-765X.1998.00358.x

[3] W. J. van der Velden, N. M. Blijlevens and J. P. Donnelly, "The Potential Role of Lactoferrin and Derivatives in the Management of Infectious and Inflammatory Complications of Hematology Patients Receiving a Hematopoietic Stem Cell Transplantation," Transplant Infectious Disease, Vol. 10, No. 2, 2007, pp. 68-71.

[4] C. C. Rosario, A. C. Lopaz, I. G. Tellez, O. A. Navarro, R. C. Anderson and C.C. Eslava, "Serotyping and Virulence Genes Detection in Escherichia coli Isolated from Fertile and Infertile Eggs, Dead-in-Shell Embryos, and Chickens with Yolk Sac Infection," Avian Diseases, Vol. 48, No. 4, 2004, pp. 791-802.

http://dx.doi.org/10.1637/7195-041304R

[5] R. R. Arnold, M. F. Cole and J. R. McGhee, "A Bactericidal Effect for Human Lactoferrin,” Science, Vol. 197, No. 4300, 1977, pp. 263-265.

http://dx.doi.org/10.1126/science.327545

[6] S. Teraguchi, K. Ozawa, S. Yasuda, K. Shin, Y. Fukuwatari and S. Shimamura, "The Bacteriostatic Effects of Orally Administered Bovine Lactoferrin on Intestinal Enterobacteriaceae of SPF Mice Fed Bovine Milk," Bioscience, Biotechnology, and Biochemistry, Vol. 58, No. 3, 1994, pp. 482-487. http://dx.doi.org/10.1271/bbb.58.482

[7] T. Susumu, S. Kouichirou, O. Tomohiro, K. Michiko, K. Akira, M. Hirofumi, F. Yasuo and S. Seiichi, "Orally Administered Bovine Lactoferrin Inhibits Bacterial Translocation in Mice Fed Bovine Milk," Applied and Environmental Microbiology, Vol. 61, No. 11, 1995, pp. 41314134.

[8] E. Lynn, B. H. Ronaldo, F. Y. Freda, R. H. Denis, A. S. Robert and P. S. Michael, "Lactoferrin Protects Neonatal Rats from Gut-Related Systemic Infection," The American Journal of Physiology-Gastrointestinal and Liver Physiology, Vol. 281, No. 5, 2001, pp. 1140-1150.

[9] M. Zimecki, J. Mazurier, G. Spik and J. A. Kapp, "Human Lactoferrin Induces Phenotypic and Functional Changes in Murine Splenic B Cells," Immunology, Vol. 86, No. 1, 1995, pp. 122-127.

[10] E. H. Coles, "Textbook of Veterinary Clinical Pathology," 4th Edition, W. B. Saunders Co., Philadelphia, 1986.

[11] K. S. Latimer, E. A. Malaffey and K. W. Prasse, "Duncan \& Prasse's Veterinary Laboratory Medicine: Clinical Pathology," 4th Edition, Iowa State Press, Iowa City, 2003.

[12] R. J. Henry, D. C. Cannon and J. W. Winkelman, "Clinical Chemistry: Principles and Techniques," Harper and Row, Hagerstown, 1974.

[13] B. Beutler and A. Cerami, "Cachectin: More than Tumor Necrosis Factor," The New England Journal of Medicine, Vol. 316, No. 7, 1987, pp. 379-385. http://dx.doi.org/10.1056/NEJM198702123160705

[14] D. Legrand "Lactoferrin, a Key Molecule in Immune and 
Inflammatory Processes," Biochemistry and Cell Biology, Vol. 90, No. 3, 2012, pp. 252-268.

http://dx.doi.org/10.1139/o11-056

[15] H. Tanaka, N. Tanaba, M. Shoji, T. Katono, S. Sato, M. Motohashi and M. Maeno, "Nicotine and Lipopolysaccharide Stimulate the Formation of Osteoclast-Like Cells by Increasing Macrophage Colony-Stimulating Factor and Prostaglandin E2 Production by Osteoblasts," Life Sciences, Vol. 78, No. 15, 2006, pp. 1733-1740. http://dx.doi.org/10.1016/j.1fs.2005.08.017

[16] P. Visca, C. Dalmastri, D. Verzili, G. Antonini, E. Chiancone and P. Valenti, "Interaction of Lactoferrin with Escherichia coli Cells and Correlation with Antibacterial Activity," Medical Microbiology and Immunology, Vol. 179, No. 6, 1990, pp. 323-333. http://dx.doi.org/10.1007/BF00189610

[17] A. H. Liliana, E. Inga, B. Lars, D. Gunnar, A. H. Lars and M. Inger, "Human Lactoferrin and Peptides Derived from a Surface-Exposed Helical Region Reduce Experimental Escherichia coli Urinary Tract Infection in Mice," Infection and Immunity, Vol. 68, No. 10, 2000, pp. 5816-5823.

[18] T. Zagulski, Z. Jarzabek, A. Zagulska, M. Jaszczak, I. E. Kochanowska and M. Zimecki, "Lactoferrin Stimulates Killing and Clearance of Bacteria but Does Not Prevent Mortality of Diabetic Mice," Archivum Immunologiae et Therapia Experimentalis, Vol. 49, No. 6, 2001, pp. 431438.

[19] A. D. Von, P. O. Hasselgren and J. E. Fischer, "Hepatic Protein Synthesis in a Modified Septic Rat Model," Journal of Surgical Research, Vol. 48, No. 5, 1990, pp. 476480. http://dx.doi.org/10.1016/0022-4804(90)90016-U

[20] M. Kinsbergen, R. M. Bruckmaier and J. W. Blum, "Metabolic, Endocrine and Haematological Responses to Intravenous E. coli Endotoxin Administration in 1-WeekOld Calves," Zentralblatt fur Veterinarmedizin Reihe A, Vol. 41, No. 7, 1994, pp. 530-547.

[21] N. A. Andréa and G. G. Loreny, "Lactoferrin and Free Secretory Component of Human Milk Inhibit the Adhesion of Enteropathogenic Escherichia coli to HeLa Cells," BMC Microbiology, Vol. 1, 2001, p. 25. http://dx.doi.org/10.1186/1471-2180-1-25

[22] J. Tanaka, T. Sato, R. T. Jones, B. F. Trump and R. A. Cowley, "The Pathophysiology of Septic Shock: Responses to Different Doses of Live Escherichia coli Injection in Rats," Advance in Shock Reserch, Vol. 9, 1983, pp. 101-114.

[23] N. C. Jain, J. L. Vegad, A. B. Shrivastava, N. K. Jain, U. K. Garg and G. N. Kolte, "Haematological Changes in Buffalo Calves Inoculated with Escherichia coli Endotoxin and Corticosteroids," Research in Veterinary Science, Vol. 47, No. 3, 1989, pp. 305-308.

[24] R. P. Richardson, C. D. Rhyne, Y. Fong, D. G. Hesse, K. J. Tracey, M. A. Marano, S. F. Lowry, A. C. Antonacci and S. E. Calvano, "Peripheral Blood Leukocyte Kinetics Following in Vivo Lipopolysaccharide (LPS) Administration to Normal Human Subjects. Influence of Elicited Hormones and Cytokines," Annals of Surgery, Vol. 210, No. 2, 1989, pp. 239-245. http://dx.doi.org/10.1097/00000658-198908000-00018

[25] J. Tong, H. Kishi, T. Matsuda and A. Muraguchi, "A Bone Marrow-Derived Stroma Cell Line, ST2, Can Support the Differentiation of Fetal Thymocytes from the CD4 ${ }^{-} \mathrm{CD} 8$ Double Negative to the $\mathrm{CD}^{+} \mathrm{CD}^{+}$Double Positive Differentiation Stage in Vitro," Immunology, Vol. 97, No. 4, 1999, pp. 672-678. http://dx.doi.org/10.1046/j.1365-2567.1999.00822.x

[26] B. Adamik, A. Wlaszczyk, M. Zimecki and A. Kübler, "Lactoferrin Effects on Immune Response in Critically Ill," 17th International Symposium on Intensive Care and Emergency Medicine, Brussels, 18-21 March 1997.

[27] K. T. Jaya and P. K. Sahoo, "Dietary Bovine Lactoferrin Induces Changes in Immunity Level and Disease Resistance in Asian Catfish Clarias Batrachus," Veterinary Immunology and Immune Pathology, Vol. 94, No. 1-2, 2003, pp. 1-9. http://dx.doi.org/10.1016/S0165-2427(03)00065-5

[28] P. M. Joseph, R. S. Matt and M. D. Claire, "Early Response Cytokines and Innate Immunity: Essential Roles for TNF Receptor 1 and Type I IL-1 Receptor during Escherichia coli Pneumonia in Mice," The Journal of Immunology, Vol. 166, No. 6, 2001, pp. 4042-4048.

[29] J. S. Theodore, "Anti-Inflammatory Cytokines and Cytokine Antagonists," Current Pharmaceutical Design, Vol. 6, No. 6, 2000, pp. 633-649. http://dx.doi.org/10.2174/1381612003400533

[30] M. Zimecki, J. Artym, G. Chodaczek, M. Kocieba and M. L. Kruzel, "Protective Effects of Lactoferrin in EScherichia coli-Induced Bacteremia in Mice: Relationship to Reduced Serum TNF Alpha Level and Increased Turnover of Neutrophils," Inflammation Research, Vol. 53, No. 7, 2004, pp. 292-296. http://dx.doi.org/10.1007/s00011-004-1257-1

[31] B. Adamik and A. Wlaszczyk, "Lactoferrin-Its Role in Defense against Infection and Immune Tropic Properties," Postępy Higieny i Medycyny Doświadczalnej, Vol. 50, No. 1, 1996, pp. 33-41.

[32] P. A. Spagnuolo, R. P. Bird and L. Hoffman-Goetz, "Effect of Short-Term Dietary Intake of Bovine Lactoferrin on Intestinal Lymphocyte Apoptosis in Healthy Mice," Nutrition, Vol. 23, No. 11-12, 2007, pp. 812-817. http://dx.doi.org/10.1016/j.nut.2007.07.006

[33] S. P. Crouch, K. J. Slater and J. Fletcher, "Cytokine Release from Mononuclear Cells by the Iron-Binding Protein Lactoferrin," Blood, Vol. 80, No. 1, 1992, pp. 235 240.

[34] W. H. Teraguchi, H. Kuwata, K. Yamauchi and Y. Tamura, "Protection against Infections by Oral Lactoferrin: Evaluation in Animal Models," BioMetals, Vol. 17, No. 3, 2004, pp. 231-234. http://dx.doi.org/10.1023/B:BIOM.0000027697.83706.32

[35] K. Yamauchi, T. Toida, S. Nishimura, E. Nagano, O. Kusuoka, S. Teraguchi, H. Hayasawa, S. Shimamura and M. Tomita, "13-Week Oral Repeated Administration Toxicity Study of Bovine Lactoferrin in Rats," Food and Chemical Toxicology, Vol. 38, No. 6, 2000, pp. 503-512. http://dx.doi.org/10.1016/S0278-6915(00)00036-3 